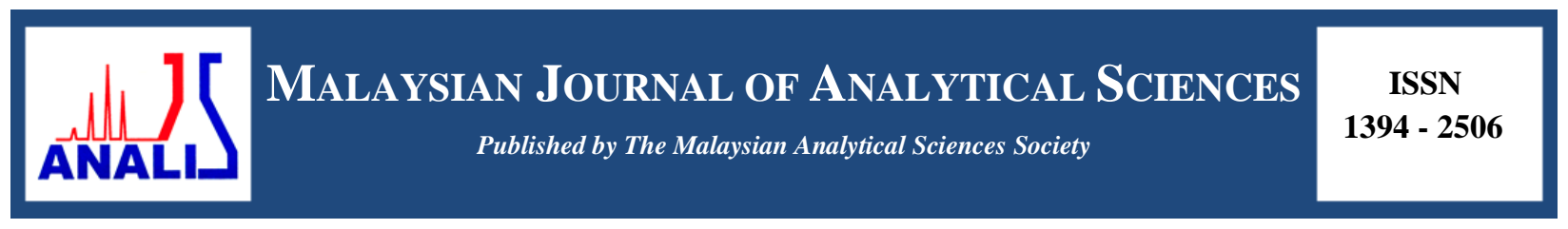

\title{
CUTICULAR HYDROCARBONS OF PUPAL CASES OF Chrysomya megacephala (FABRICIUS) AND ITS POSSIBLE USE FOR ESTIMATING POSTMORTEM INTERVAL
}

\author{
(Hidrokarbon Kutikel Kepompong Chrysomya megacephala dan Kegunaannya untuk \\ Menganggar Sela Masa Kematian) \\ Nurul Nadhirah Nasir ${ }^{1}$, Mohamad Afiq Mohamed Huri ${ }^{1}$, Reena Abd. Rashid ${ }^{2}$, Jaafariah Jaafar ${ }^{1}$, \\ Naji Arafat Mahat ${ }^{1} *$ \\ ${ }^{1}$ Department of Chemistry, Faculty of Science, \\ Universiti Teknologi Malaysia, 81310 UTM Johor Bahru, Johor, Malaysia \\ ${ }^{2}$ Chemistry (Forensic Analysis) Programme, Faculty of Applied Sciences, \\ Universiti Teknologi MARA, 40450 Shah Alam, Selangor, Malaysia \\ *Corresponding author: naji@kimia.fs.utm.my
}

Received: 25 October 2017; Accepted: 22 January 2019

\begin{abstract}
Pupal cases of Chrysomya megacephala are commonly found at death scenes; however, its utilization for forensic investigation remains nascent. Although the use of cuticular hydrocarbons ( $\mathrm{CHCs}$ ) for estimating the age of pupal cases has been reported, they were either laboratory-controlled experiments or in environmental conditions peculiar to Malaysia. Hence, this present research examined the $\mathrm{CHCs}$ in the pupal cases of $C$. megacephala exposed to the natural weathering in Malaysia provides empirical evidence for its age estimation. While confirmation of the identity of CHCs was done using gas chromatographymass spectrometry, gas chromatography-flame ionization detector was used for quantifying the concentrations. The hexane extract of the pupal cases of $C$. megacephala contained a mixture of odd-numbered high molecular weight aliphatic (heptacosane $(n$-C27) and nonacosane $(n-\mathrm{C} 29))$, and branched alkanes (tetradecane, 2,6,20-trimethyl- and octadecane, 3-ethyl5-(2-ethylbutyl)). Significant decrease $(p<0.05)$ in the concentrations of $\mathrm{n}-\mathrm{C} 27$ and $\mathrm{n}$-C29 was observed, with the pattern being highly correlated $(r>-0.926)$ with that of subsequent weathering intervals. Such findings had enabled formulation of credible mathematical algorithms for relating the concentrations of $n-\mathrm{C} 27$ and $n$-C29 in the pupal cases of $C$. megacephala versus the natural weathering intervals for its age estimation in Malaysia.
\end{abstract}

Keywords: forensic science, cuticular hydrocarbon, Chrysomya megacephala, postmorterm interval, Malaysia

\section{Abstrak}

Kepompong Chrysomya megacephala biasa dijumpai di tempat penemuan kematian; namun, penggunaanya dalam penyiasatan forensik masih baharu. Meskipun penggunaan kutikel hidrokarbon (CHC) dalam menganggar umur kepompong telah dilaporkan, ia sama ada dijalankan dalam ujikaji makmal terkawal ataupun dalam keadaan persekitaran yang janggal untuk Malaysia. Justeru, kajian ini yang menyelidik CHC dalam kepompong C. megacephala terdedah kepada proses luluhawa semulajadi di Malaysia memberikan bukti empirikal dalam menganggar usianya. Pengesahan identiti CHC dilakukan dengan menggunakan kromatografi gas-spektrometer jisim, manakala kromatografi gas-pengesan nyalaan pengionan digunakan untuk menentukan kepekatannya. Ekstrak heksana kepompong $C$. megacephala mengandungi campuran alifatik molekul berat yang bernombor ganjil (heptakosana ( $n$-C27) dan nonakosana (n-C29)) dan alkana bercabang (tetradekana, 2,6,20-trimetil- dan oktadekana, 3etil-5-(2-etilbutil)). Penurunan signifikan $(p<0.05)$ dalam kepekatan $n$-C27 dan $n$-C29 dapat diperhatikan, dengan corak penurunan berkorelasi tinggi $(r>-0.926)$ dengan sela masa luluhawa. Penemuan tersebut membolehkan perumusan algoritma matematik yang mapan bagi mengaitkan kepekatan $n-\mathrm{C} 27$ dan $n$-C29 dalam kepompong C. megacephala dengan sela masa luluhawa semula jadi untuk menganggar usianya di Malaysia. 


\section{Nurul Nadhirah et al: CUTICULAR HYDROCARBONS OF PUPAL CASES OF Chrysomya megacephala (FABRICIUS) AND ITS POSSIBLE USE FOR ESTIMATING POSTMORTEM INTERVAL}

Kata kunci: sains forensik, hidrokarbon kutikel, Chrysomya megacephala, sela masa kematian, Malaysia

\section{Introduction}

Forensic entomology deals with utilization of insect evidence for providing accurate estimation of minimum postmortem interval (mPMI) from the developmental patterns of necrophagous insects [1, 2]. In Peninsular Malaysia, Chrysomya megacephala (Fabricius) (Diptera: Calliphoridae) has been reported as the first and dominant necrophagus species infesting dead bodies and/or animal models followed by Chrysomya rufifacies (Macquart) (Diptera: Calliphoridae) [3, 4]. Being the first infesting necrophagous species in Malaysia, estimation of mPMI using the developmental pattern of $C$. megacephala may prove as the most appropriate. Studies have indicated that the duration for completing the life cycle for C. megacephala ranges between 7.25 to 8 days [4-6] beyond which estimation of PMI has to rely on the developmental patterns of the subsequent necrophagous insects such as $C$. rufifacies. It is pertinent to indicate here that upon completion of the life cycle, pupal cases of $C$. megacephala are commonly found at crime scenes [1]. However, its evidential value for estimating PMI remains scarcely reported in the body of literature. In this context, developing a means for assessing the age of those pupal cases may be useful for estimating the mPMI, considering the fact that $C$. megacephala being the first necrophagous insect to oviposit in corpses in many countries including Malaysia. Although the application of cuticular hydrocarbon (CHC) analysis for estimating the age of pupal cases of C. megacephala [7, 8] and larvae of $C$. rufifacies [9] has been suggested, these studies pertained to either laboratory setting or without adequate indication on the ambient conditions where the field experiments were conducted.

Zhu et al. [8], while reporting on the regular changes of $\mathrm{CHC}$ composition in the pupal cases of $C$. megacephala in China, indicated that the range of means of daily ambient temperature, relative humidity and the overall total rainfall for the 90 days of sampling period as $9.4-22.8{ }^{\circ} \mathrm{C}, 35-91 \%$ and 72.9 mm, respectively. However, they did not report the actual daily ambient data and the total daily rainfall in the field experiment that they conducted. In contrast to the description of the general conditions that they described [8], the ambient temperature in the low land areas of Malaysia has been reported to range between $21.5^{\circ} \mathrm{C}$ to $36.3^{\circ} \mathrm{C}$, with rain being a commonplace occurrence [10]. Considering the migratory behavior of the post-feeding larvae of $C$. megacephala and their tendency to bury themselves into the surrounding soil for pupating [11], findings reported by Zhu et al. [8] by which the pupal cases 'was placed on the grass land with sandy soil and some shrubs' may not reflect the natural condition in Malaysia. In addition, different habitats may have different composition of soil types that may potentially influence the CHC compositions of pupal cases of necrophagous insects, an avenue for further research.

Therefore, this present research aiming at providing the first ever empirical data for exploring the possible use of CHC compositions in the pupal cases of C. megacephala exposed to natural weathering conditions prevailing in Malaysia for forensic use at estimating the minimum PMI, acquires significance.

\section{Chemicals and reagents}

\section{Materials and Methods}

The chemicals used in this present research were: $n$-C21 to $n-\mathrm{C} 40(50 \mathrm{mg} / \mathrm{L})$ alkane standard (Fluka, USA) and analytical grade n-hexane (QRec, New Zealand). The ultrapure water produced by Biopak Polisher (Merck, Germany) was used without further purification. Stock solution that contained 20 alkane standards (n-C21 to nC40) $(50 \mathrm{mg} / \mathrm{L})$ was used. From the standard stock solution, six working solutions were prepared using hexane via serial dilution; $5,10,20,30,40$ and $50 \mu \mathrm{g} / \mathrm{mL}$.

\section{Experimental design}

A total of 24 pupal cases of $C$. megacephala were collected from decomposing beef substrates in a sunlit habitat within the UTM Skudai Campus (1³3'45.6" N, 10339'09.2" E) (Figure 1(a)), located at about 41.47 $\mathrm{m}$ above the sea level, and the soil type was loam. Physical characterization of the soil was made following the description provided by previous researchers [12]. For studying the temporal variations of CHC profiles, the pupal cases (Figure 1(b)) were exposed to the weathering process at day-0, day-7 and day-14. During each 
weathering interval, three samples (each sample consisted of eight pupal cases) were analysed.

For enabling easier sampling while mimicking the natural behavior, pupal cases were buried at about $3 \mathrm{~cm}$ below the soil surface, approximately $1 \mathrm{~m}$ radius surrounding the decomposing substrates. Such a radius and depth were chosen due to the dispersal behavior of the post feeding larvae of $C$. megacephala as indicated by the previous researchers [11]. The daily ambient temperature and relative humidity were recorded in situ using a digital data logger, while a calibrated rain gauge was utilized for recording the total daily rainfall during observation period.
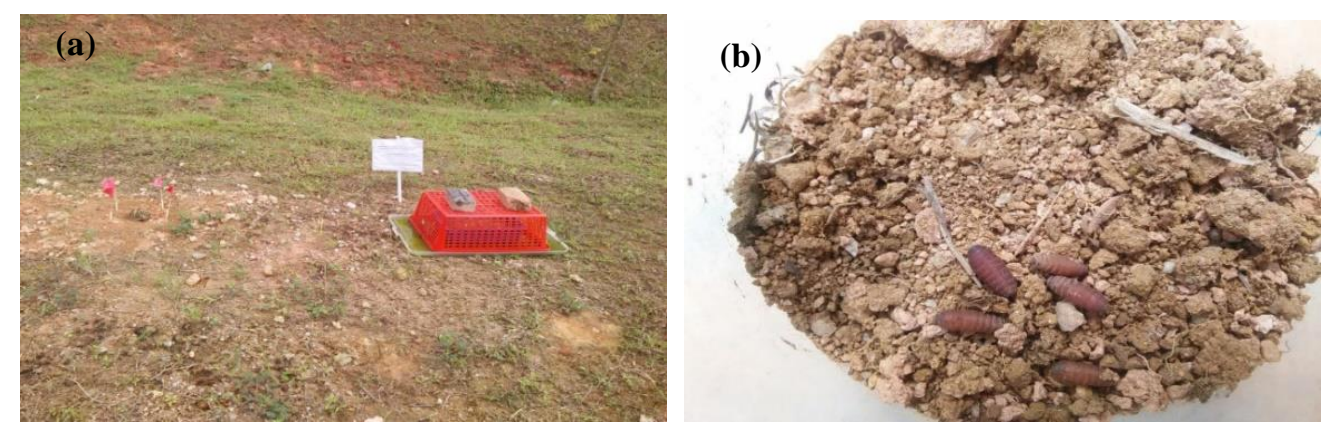

Figure 1. Photographs of (a) decomposition and burial site, as well as (b) sample of pupal cases of $C$. megacephala collected from soil surrounding a representative beef substrate decomposing in UTM Skudai Campus exposed to the weathering process at day-7

\section{Sample pre-treatment}

In this study, the pre-treatment step was conducted with minor modification from the methods described in past literature [8]. A sample (eight pupal cases each) collected for a particular interval of observation was cleaned using ultrapure water with the aid of a small tip drawing brush for removing the attached soil, dried using a clean filter paper and weighed. To extract the CHC, sample was immersed in n-hexane $(800 \mu \mathrm{L})$ and vortexed for 10 mins. Extracted sample was concentrated under a stream of nitrogen gas and dissolved in n-hexane $(50 \mu \mathrm{L})$ for quantitative and qualitative analyses using gas chromatography-flame ionization detector (GC-FID) and gas chromatography-mass spectrometry (GC-MS), respectively. Using the commercial alkane standard (n-C21 to n$\mathrm{C} 40$ ), a daily chromatographic run was performed for evaluating the linearity of the analytical response, as well as ascertaining the identity of CHC that may be present in the extracted sample.

\section{Analytical instrumentations}

The analytical conditions for analyzing CHCs using GC-MS and GC-FID were optimized in situ and the conditions are tabulated in Table 1.

Table 1. The analytical conditions used for GC-FID and GC-MS.

\begin{tabular}{|c|c|c|}
\hline \multirow{2}{*}{$\begin{array}{l}\text { Parameter } \\
\text { Instrument }\end{array}$} & \multicolumn{2}{|c|}{ Conditions } \\
\hline & $\begin{array}{l}\text { GC-FID } \\
\text { (7890B GC Agilent, Australia) }\end{array}$ & $\begin{array}{l}\text { GC-MS } \\
\text { (7890B GC coupled with } 7010 \text { MS, } \\
\text { Agilent, Australia) }\end{array}$ \\
\hline Carrier Gas & Helium & Helium \\
\hline Capillary Column & $\begin{array}{l}\text { HP-5 capillary column } \\
(30 \mathrm{~m} \times 0.320 \mathrm{~mm} \text { i.d., } 0.25 \mu \mathrm{m} \text { film })\end{array}$ & $\begin{array}{l}\text { HP-5MS capillary column } \\
(60 \mathrm{~m} \times 0.250 \mathrm{~mm} \text { i.d., } 0.25 \mu \mathrm{m} \text { film })\end{array}$ \\
\hline Injection Mode & Splitless & \\
\hline
\end{tabular}




\section{Nurul Nadhirah et al: CUTICULAR HYDROCARBONS OF PUPAL CASES OF Chrysomya megacephala (FABRICIUS) AND ITS POSSIBLE USE FOR ESTIMATING POSTMORTEM INTERVAL}

Table 1 (cont'd). The analytical conditions used for GC-FID and GC-MS.

\begin{tabular}{llc}
\hline Parameter & \multicolumn{1}{c}{ Conditions } \\
\hline Injection Volume & $1 \mu \mathrm{L}$ & \\
Injector Temperature & $280^{\circ} \mathrm{C}$ & $300^{\circ} \mathrm{C}$ \\
Detector Temperature & $330^{\circ} \mathrm{C}$ & \\
Oven Temperature & Initial temperature of $200^{\circ} \mathrm{C}$ (held for 1 min); ramped to $230^{\circ} \mathrm{C}$ at $15^{\circ} \mathrm{C} / \mathrm{min} ;$ \\
& ramped to $310^{\circ} \mathrm{C}$ at $5^{\circ} \mathrm{C} / \mathrm{min}$ (held for 20 mins) \\
Analytical Software & - & Mass Hunter \\
Major and Confirmatory & - & n-C27 (major: 85, confirmatory: 380) \\
Ions $(\mathrm{m} / \mathrm{z})$ & & n-C29 (major: 85, confirmatory: 408) \\
\hline
\end{tabular}

\section{Statistical analyses}

Data analyses were performed using the IBM-SPSS version 20.0 software and the normality of data for statistical inference was tested using Shapiro-Wilks. All the data were normally distributed with the $p$ values for Shapiro-Wilks exceeding 0.05. For comparing the concentrations of $n$-C27 and $n$-C29 in pupal cases of $C$. megacephala at three different weathering intervals (day-0, 7 and 14), one-way analysis of variance (ANOVA) with Tukey-Kramer post hoc test was used. For associating the concentrations of $n$-C27 and $n$-C29 with that of weathering intervals, Pearson correlation coefficient analysis was utilized. Level of significance of 0.05 was considered for assigning the significance among groups [13].

\section{Calibration curve, LOD and LLOQ}

\section{Results and Discussion}

While confirmation of the identity for Heptacosane (n-C27) and nonacosane (n-C29) was done using GC-MS (7890B GC coupled with 7010 MS, Agilent, Australia), quantitation of such compounds was made using GC-FID (7890B GC Agilent, Australia). The representative chromatograms generated from GC-MS and GC-FID for $n$ $\mathrm{C} 21$ to $n$-C40 standard mixture are presented in Figures 2(a)-(b), respectively. All the hydrocarbon standards were well separated with total separation times for the 20 hydrocarbons using GC-MS and GC-FID being about 31 and 30 mins, respectively. Using GC-MS, $n$-C27 and $n$-C29 from the pupal cases (day-0) eluted at 10.956 and 13.316 mins, respectively (Figure 3(a)); the same eluted at 10.963 and 13.276 mins from GC-FID (Figure 3(b)). The mass spectra for $n$-C27 and $n$-C29 from the NIST library, as well as those obtained from representative samples are presented in Figures 4-5. Following the recommendation made by Miuc et al. [14], ions (m/z) 85 and 380 were used for confirming the identity of $n$-C27; the same were 85 and 408 for $n$-C29.
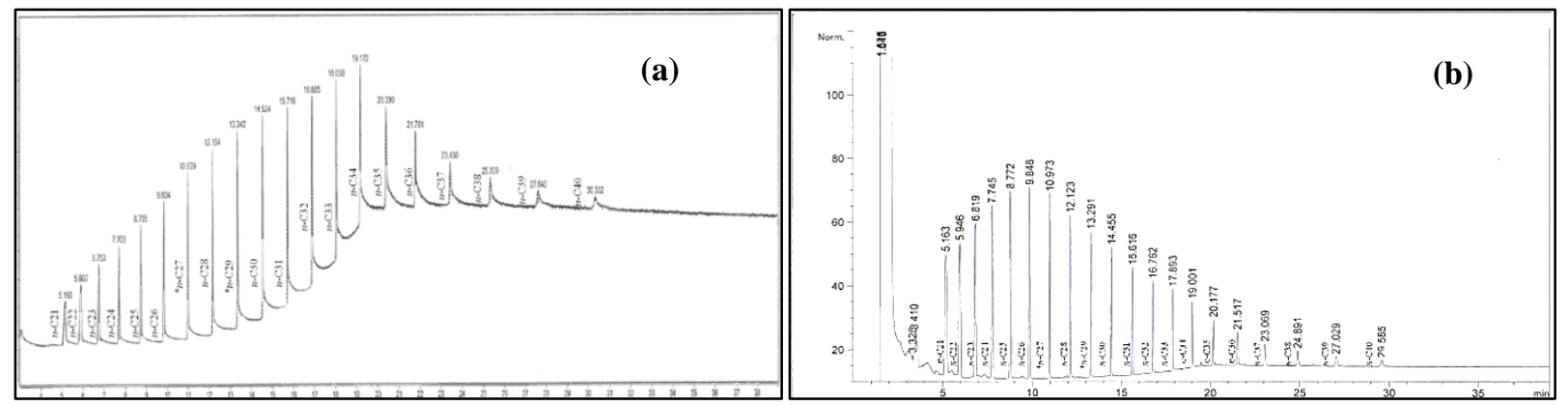

Figure 2. GC-MS (a) and GC FID (b) chromatograms obtained for $n$-C21- $n$-C40 standard mixture. Heptacosane $(n-\mathrm{C} 27)$ and nonacosane $(n-\mathrm{C} 29)$ were used for comparison and regression studies 

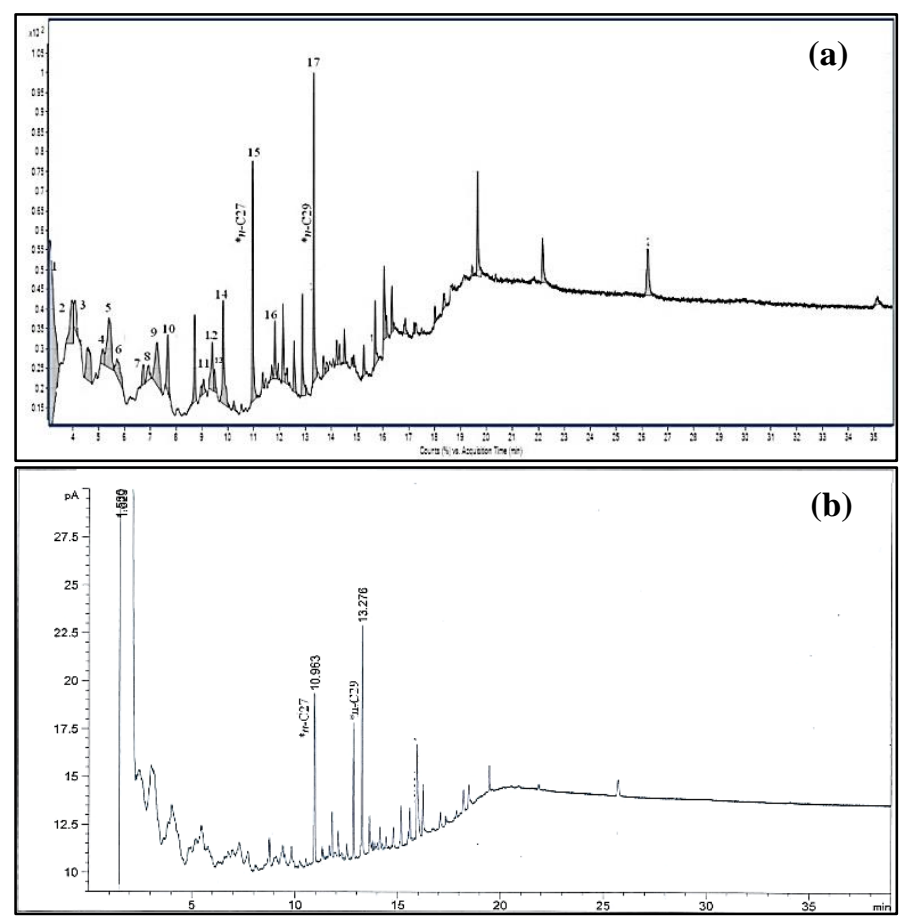

Figure 3. GC-MS (a) and GC-FID (b) representative chromatograms of CHC for C. megacephala pupal case at Day-0. Heptacosane $(n-\mathrm{C} 27)$ and nonacosane $(n-\mathrm{C} 29)$ were used for comparison and regression studies.

Table 2. Analytical figures of merit for hydrocarbons analysed.

\begin{tabular}{lccccc}
\hline $\begin{array}{l}\text { Two Prevailing } \\
\text { Hydrocarbons }\end{array}$ & $\begin{array}{c}\text { Range of } \\
\text { Calibration Curve } \\
(\boldsymbol{\mu g} / \mathbf{m L})\end{array}$ & $\begin{array}{c}\text { Coefficient of } \\
\text { Determination } \\
\left(\mathbf{R}^{\mathbf{2}}\right)\end{array}$ & Equation & $\begin{array}{c}\text { LOD } \\
(\boldsymbol{\mu g} / \mathbf{m L})\end{array}$ & $\begin{array}{c}\text { LLOQ } \\
(\boldsymbol{\mu g} / \mathbf{m L})\end{array}$ \\
\hline $\begin{array}{l}\text { Heptacosane } \\
(n-\mathrm{C} 27)\end{array}$ & $0-50$ & 0.9978 & $\mathrm{y}=2.2712 \mathrm{x}+2.1462$ & 3.68 & 5.58 \\
$\begin{array}{l}\text { Nonacosane } \\
(n-\mathrm{C} 29)\end{array}$ & $0-50$ & 0.9974 & $\mathrm{y}=1.7094 \mathrm{x}+8.8207$ & 4.77 & 7.22 \\
\hline
\end{tabular}

The guideline prescribed by the USFDA [15] was used for accepting the calibration curves, as well as LODs and LLOQs. The calibration curve was accepted when $\mathrm{R}^{2} \geq 0.995$. The LOD and LLOQ were mathematically calculated using signal-tonoise ratios of $3: 1$ and $5: 1$, respectively.

\section{Analysis of CHC compositions in pupal cases of $\boldsymbol{C}$. megacephala}

It is pertinent to indicate here that in Malaysia, upon reaching the fully grown stage of third instar larvae, $C$. megacephala would start to wander away from the decomposing corpses/carcasses and pupate by burying themselves in the surrounding soil until the emergence of tenerals [11]. Hence, it is expected that, in forensic investigation, the pupal cases of this necrophagous species can largely be found at about 1-3 cm underneath the soil surface [4]. Such a condition does not only lead to the abiotic (weathering) degradation of CHC in the pupal cases, but also leaving them fully exposed to biodegradation by soil-microbiota [17, 18]. Despite its unique post-feeding behavior and the possible influence of soil microbiota on CHC biodegradation of pupae and pupal cases of $C$. megacephala, specific discussion on this aspect, in view of its forensic application, remains unreported so far. 


\section{Nurul Nadhirah et al: CUTICULAR HYDROCARBONS OF PUPAL CASES OF Chrysomya megacephala (FABRICIUS) AND ITS POSSIBLE USE FOR ESTIMATING POSTMORTEM INTERVAL}

Review of literature reveals no specific study focusing on CHC compositions in pupae and pupal cases of necrophagous insects exposed to weathering conditions in tropical countries like Malaysia. Except for only one reported field study [8] (daily ambient temperature: $9.4-22.8{ }^{\circ} \mathrm{C}$, daily relative humidity: $35-91 \%$, total rainfall: 72.9 $\mathrm{mm}$ ) with the ambient conditions peculiar for tropical countries like Malaysia, the remaining studies were conducted in laboratory-controlled conditions detailed below. While Ye et al. [19] conducted their pupae weathering experiment at constant $24{ }^{\circ} \mathrm{C}$ and $75 \%$ relative humidity using sawdust as the rearing medium, Zhu et al. [7] did the same at $25 \pm 1{ }^{\circ} \mathrm{C}$ with photoperiod of $14: 10 \mathrm{~h}$ (light: dark). In another laboratory study, Frere et al. [20] compared the CHC compositions in the new (year 2012) and old (year 1997) pupal cases of Hydrotaea aenescens (Diptera: Muscidae) although the weathering conditions were not indicated. Generalization of the findings from other biogeoclimatic regions $[7,19,20]$ for interpreting the CHC data in pupae and pupal cases of necrophagous insects found in tropical countries may prove to be erroneous. Therefore, the specific attempt made in this present research at examining $\mathrm{CHC}$ compositions in the pupal cases of $C$. megacephala buried at about $3 \mathrm{~cm}$ underneath the surrounding soil at three different weathering intervals (day-0, day-7 and day-14) in Malaysia acquires forensic significance. Recognizing the possibility of using CHC compositions in the pupal cases of $C$. megacephala for estimating mPMI, and because climatological factors [21-24] can potentially influence its composition, the data viz. ambient temperature, relative humidity and total rainfall were recorded here too.

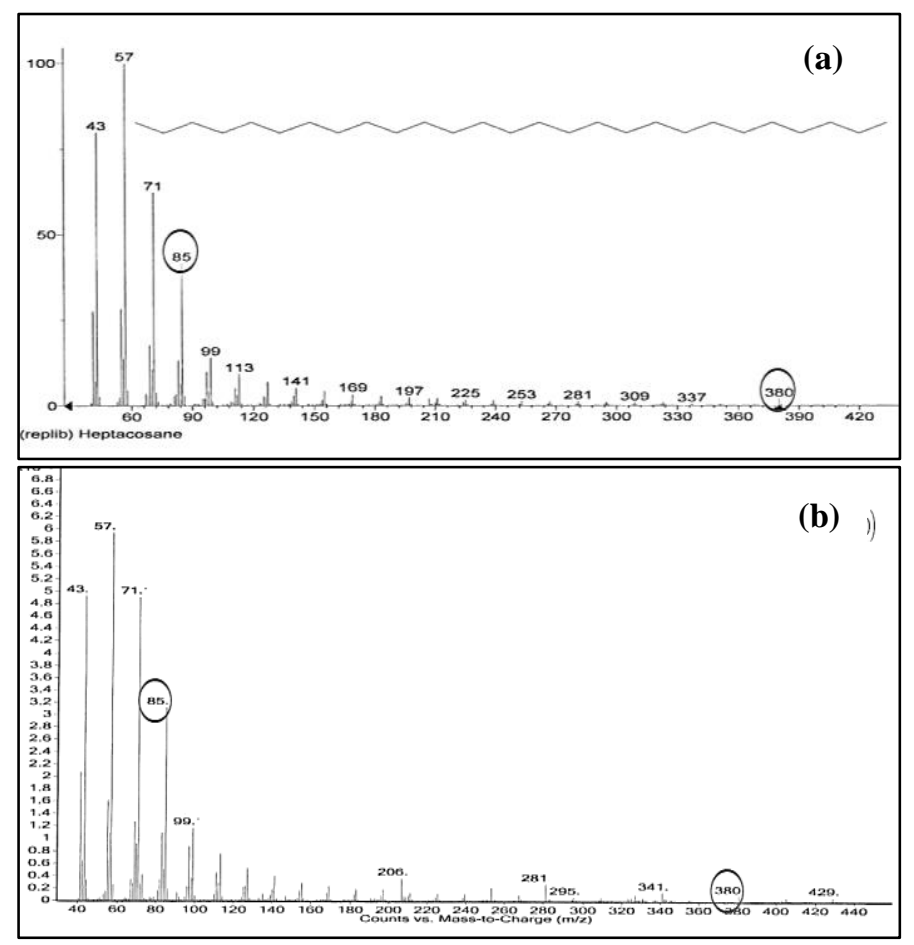

Figure 4. Mass spectrum for heptacosane ( $n$-C27) from (a) the NIST library and (b) a sample. As suggested by Miuc et al. [14], m/z 85 and 380 were used as the major and confirmatory ions, respectively 

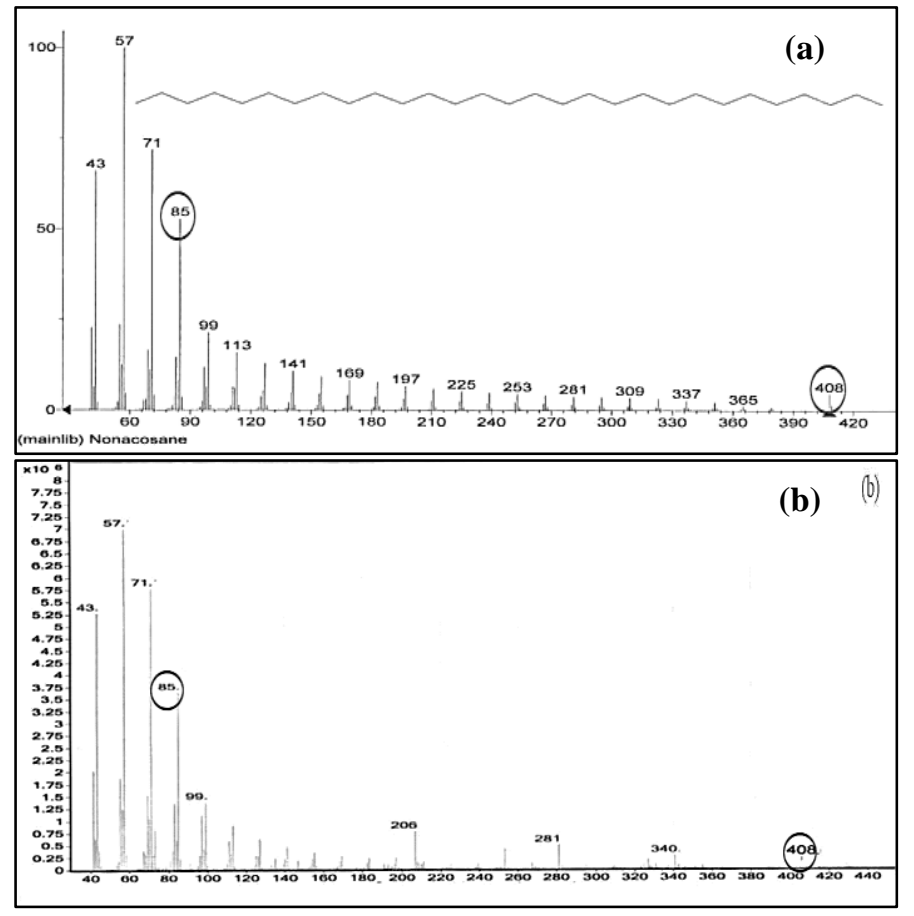

Figure 5. Mass spectrum for nonacosane ( $n$-C29) from (a) the NIST library and (b) a sample. As suggested by Miuc et al. [14], m/z 85 and 408 were used as the major and confirmatory ions, respectively.

\section{Climatological conditions}

The data on daily ambient temperature and relative humidity, as well as the daily total rainfall at the decomposition site are tabulated in Table 3. It was observed that the daily ambient temperature during the span of observation period (day-0 until day-14) ranged between $28.2-30.1^{\circ} \mathrm{C}$ with the overall means during day-7 and day-14 being $29.5 \pm 0.5$ and $29.3 \pm 0.7$, respectively. Such a low variation in the ambient temperature recorded here was consistent with indication made by Trewin [25] that the differences in ambient temperature between the warmest and coldest months in the tropics only ranged between $1-4{ }^{\circ} \mathrm{C}$. In addition, the daily relative humidity recorded here ranged between $75.7-95 \%$ (mean \pm SD: $84.8 \pm 4.2 \%$ ) with the highest and lowest humidity recorded on day- 2 and day- 8 , respectively. The highest relative humidity observed on day-2 (95.2\%) may be attributable to the presence of heavy rain $(12.6 \mathrm{~mm})$ during that day. As for the daily total rainfall during the span of observation period, the amounts ranged between 0.0-12.6 mm. 
Nurul Nadhirah et al: CUTICULAR HYDROCARBONS OF PUPAL CASES OF Chrysomya megacephala (FABRICIUS) AND ITS POSSIBLE USE FOR ESTIMATING POSTMORTEM INTERVAL

Table 3. Daily ambient temperature, relative humidity and daily total rainfall recorded during the observation period $\left(16^{\text {th }}-30^{\text {th }}\right.$ November 2016).

\begin{tabular}{|c|c|c|c|c|c|}
\hline \multirow[b]{2}{*}{ Days } & \multicolumn{2}{|c|}{ Temperature $\left({ }^{\circ} \mathbf{C}\right)$} & \multicolumn{2}{|c|}{ Humidity (\%) } & \multirow{2}{*}{$\begin{array}{c}\text { Daily Total } \\
\text { Rainfall } \\
\text { (mm) and Its } \\
\text { Duration } \\
\text { (symbol) }\end{array}$} \\
\hline & Mean \pm SD & Ranges & Mean \pm SD & Ranges & \\
\hline$\overline{0 *}$ & 28.6 & 28.6 & 86.2 & 86.2 & $0.4(\square)$ \\
\hline 1 & $28.6 \pm 0.9$ & $25.7-29.7$ & $83.1 \pm 4.2$ & $78.9-87.3$ & 0.0 (㘯) \\
\hline 2 & $29.3 \pm 0.5$ & $27.9-30.0$ & $90.7 \pm 4.5$ & $86.2-95.2$ & $12.6(\square)$ \\
\hline 3 & $29.2 \pm 0.6$ & $28.4-30.0$ & $85.3 \pm 4.3$ & $81.0-89.6$ & $0.8(\boldsymbol{*})$ \\
\hline 4 & $29.5 \pm 0.5$ & $28.8-30.4$ & $83.1 \pm 4.1$ & $78.9-87.3$ & $0.2(\boldsymbol{\beta})$ \\
\hline 5 & $29.8 \pm 0.7$ & $28.9-30.9$ & $86.4 \pm 4.3$ & $82.1-90.7$ & $2.4(\square)$ \\
\hline 6 & $30.0 \pm 0.3$ & $29.5-30.5$ & $83.3 \pm 4.2$ & $79.1-87.5$ & $0.4(\boldsymbol{\varkappa})$ \\
\hline 7 & $29.8 \pm 0.5$ & 29.1-30.6 & $82.5 \pm 4.1$ & $78.1-86.6$ & 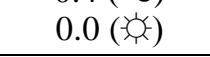 \\
\hline $\begin{array}{l}\begin{array}{l}\text { Overall mean and } \\
\text { (range) of day-7 }\end{array} \\
\end{array}$ & $29.5 \pm 0.5$ & $(28.6-30.0)$ & $84.9 \pm 4.2$ & (78.9-95.2) & $(0.0-2.6)$ \\
\hline 8 & $30.1 \pm 0.5$ & $29.2-31.0$ & $82.3 \pm 4.1$ & $75.7-86.4$ & 0.0 (架) \\
\hline 9 & $29.8 \pm 0.8$ & $28.1-31.0$ & $88.7 \pm 4.4$ & $81.6-93.1$ & $6.4(\square)$ \\
\hline 10 & $29.7 \pm 0.4$ & $29.1-30.5$ & $87.5 \pm 4.4$ & $83.1-91.9$ & $4.6(\square)$ \\
\hline 11 & $29.3 \pm 0.3$ & $28.5-29.8$ & $82.7 \pm 4.1$ & $78.6-86.8$ & 0.0 (必) \\
\hline 12 & $29.4 \pm 0.3$ & $28.9-30.1$ & $82.9 \pm 4.1$ & $76.3-87.0$ & 0.0 (㤎) \\
\hline 13 & $28.2 \pm 0.8$ & $26.2-29.4$ & $82.6 \pm 4.1$ & $78.5-86.7$ & $0.0\left(\begin{array}{l}0 \\
0\end{array}\right)$ \\
\hline 14 & $28.4 \pm 0.7$ & $27.4-29.3$ & $84.6 \pm 4.2$ & $77.8-88.8$ & $0.8(\boldsymbol{\bullet})$ \\
\hline $\begin{array}{l}\begin{array}{l}\text { Overall mean and } \\
\text { (range) of day-14 }\end{array} \\
\end{array}$ & $29.3 \pm 0.7$ & $(28.2-30.1)$ & $84.5 \pm 4.2$ & (75.7-93.1) & $(0.0-6.4)$ \\
\hline $\begin{array}{l}\begin{array}{l}\text { Overall mean and } \\
\text { (range) of observation } \\
\text { period }\end{array} \\
\text { perion }\end{array}$ & $29.3 \pm 0.6$ & $28.2-30.1$ & $84.8 \pm 4.2$ & $75.7-95.2$ & $(0.0-12.6)$ \\
\hline
\end{tabular}

Day-0 refers to the day tenerals emerged from the pupae. While the ambient temperature and relative humidity were recorded at every two-hour interval in-situ using a data logger, the daily total rainfall was recorded using a rain gauge.

Legend: no rain (

It is paramount to mention that ambient temperature plays pivotal roles at influencing the composition of CHC [23, 26]. High temperature $\left(35-40^{\circ} \mathrm{C}\right)$ has been associated with larger amount of long chain n-alkanes ( $n$-C21 to $n$ C36) than that of at lower temperature [21-24, 27]. Similarly, insects that are exposed to low relative humidity (10$3 \%$ ) have been reported to contain larger amount of long chain n-alkanes when compared with that of higher ones (95-100\%). Since the climatological condition reported here was largely different from a field work reported by Zhu et al. [8], the need for conducting this present research in Malaysia for forensic application appears imperative.

Despite the possibility of ambient temperature, humidity and rainfall being factors affecting CHC compositions in necrophagous insects, laboratory experiments conducted by others [20,26] also did not provide such information. Since in real forensic applications 'Calliphoridae collected from the field experience constant fluctuation in both temperature and humidity' [26], this present research that evaluated the CHC compositions in pupal cases of C. megacephala buried in soil under field conditions in a tropical country like Malaysia where rain is commonplace, deserves specific forensic consideration. 


\section{Changes of $\mathrm{CHC}$ profiles in the pupal cases over the stipulated weathering intervals}

Analysis of the hexane extract of the pupal cases of $C$. megacephala (Table 4) revealed a mixture of mostly oddnumbered high molecular weight ( $\geq 18$ carbons [28]) aliphatic (i.e. $n$-C27 and $n$-C29) and branched alkanes (i.e. tetradecane,2,6,20-trimethyl- and octadecane,3-ethyl-5-(2-ethylbutyl)-). Only four peaks that represented tetradecane $(n$-C17) can be classified as low molecular weight hydrocarbons. This was consistent with the findings of the previous researchers, indicating the great mass abundance of odd-numbered high molecular weight aliphatic hydrocarbons in the pupal cases of $C$. megacephala exposed to the field weathering process in Guangdong, China [8].

Table 4. Mean $( \pm \mathrm{SD})$ relative abundance of CHCs in pupal cases of $C$. megacephala exposed to three natural weathering intervals using GCMS

\begin{tabular}{|c|c|c|c|c|c|c|c|}
\hline \multirow[t]{2}{*}{ Peaks } & \multirow{2}{*}{$\begin{array}{c}\text { Retention } \\
\text { Time }\end{array}$} & \multirow[t]{2}{*}{ CHC } & \multirow[t]{2}{*}{ Classification } & \multirow[t]{2}{*}{ Chemical Name } & \multicolumn{3}{|c|}{ Mean \pm SD relative abundance } \\
\hline & & & & & Day-0 & Day-7 & Day-14 \\
\hline$\overline{1}$ & 3.082 & $\mathrm{C}_{17} \mathrm{H}_{36}$ & Branched alkane & Tetradecane, $2,6,10-$ & $25.98 \pm 1.30$ & $27.00 \pm 1.35$ & $40.4 \pm 2.02$ \\
\hline 2 & 3.965 & $\mathrm{C}_{17} \mathrm{H}_{36}$ & Branched alkane & Tetradecane, $2,6,10-$ & $3.08 \pm 0.15$ & $22.91 \pm 1.14$ & $0.76 \pm 0.04$ \\
\hline 3 & 4.084 & $\mathrm{C}_{17} \mathrm{H}_{36}$ & Branched alkane & Tetradecane, 2,6,10- & $1.91 \pm 0.10$ & undetected & undetected \\
\hline 4 & 5.160 & $\mathrm{C}_{27} \mathrm{H}_{56}$ & $\mathrm{~N}$-alkane & Heptacosane & $6.32 \pm 0.32$ & $0.92 \pm 0.05$ & $0.67 \pm 0.03$ \\
\hline 5 & 5.389 & $\mathrm{C}_{17} \mathrm{H}_{36}$ & Branched alkane & Tetradecane, 2,6,10- & $4.84 \pm 0.24$ & $4.13 \pm 0.21$ & undetected \\
\hline 6 & 5.711 & $\mathrm{C}_{27} \mathrm{H}_{56}$ & N-alkane & Heptacosane & $2.15 \pm 0.11$ & $1.97 \pm 0.10$ & undetected \\
\hline 7 & 6.743 & $\mathrm{C}_{27} \mathrm{H}_{56}$ & N-alkane & Heptacosane & $0.90 \pm 0.45$ & undetected & undetected \\
\hline 8 & 6.919 & $\mathrm{C}_{27} \mathrm{H}_{56}$ & N-alkane & Heptacosane & $0.94 \pm 0.05$ & undetected & undetected \\
\hline 9 & 7.261 & $\mathrm{C}_{27} \mathrm{H} 56$ & N-alkane & Heptacosane & $4.93 \pm 0.25$ & $3.94 \pm 0.20$ & $3.19 \pm 0.16$ \\
\hline 10 & 7.673 & $\mathrm{C}_{27} \mathrm{H}_{56}$ & N-alkane & Heptacosane & $3.13 \pm 0.16$ & $2.58 \pm 0.13$ & $2.37 \pm 0.12$ \\
\hline 11 & 9.057 & $\mathrm{C}_{27} \mathrm{H}_{56}$ & $\mathrm{~N}$-alkane & Heptacosane & $2.62 \pm 0.13$ & $1.66 \pm 0.08$ & $0.63 \pm 0.03$ \\
\hline 12 & 9.389 & $\mathrm{C}_{27} \mathrm{H}_{56}$ & $\mathrm{~N}$-alkane & Heptacosane & $3.40 \pm 0.17$ & $2.63 \pm 0.13$ & $2.37 \pm 0.12$ \\
\hline 13 & 9.475 & $\mathrm{C}_{26} \mathrm{H}_{54}$ & Branched alkane & Octadecane, 3-ethyl- & $0.69 \pm 0.03$ & $1.28 \pm 0.06$ & $0.70 \pm 0.05$ \\
\hline 14 & 9.811 & $\mathrm{C}_{27} \mathrm{H}_{56}$ & $\mathrm{~N}$-alkane & Heptacosane & $4.58 \pm 0.22$ & $3.05 \pm 0.15$ & $2.59 \pm 0.13$ \\
\hline $15^{*}$ & 10.956 & $\mathrm{C}_{27} \mathrm{H}_{56}$ & N-alkane & Heptacosane & $6.23 \pm 0.31$ & $1.57 \pm 0.08$ & $1.09 \pm 0.05$ \\
\hline 16 & 11.812 & $\mathrm{C}_{26} \mathrm{H}_{54}$ & Branched alkane & Octadecane, 3-ethyl- & $1.54 \pm 0.08$ & undetected & undetected \\
\hline $17 *$ & 13.316 & $\mathrm{C}_{29} \mathrm{H}_{60}$ & N-alkane & Nonacosane & $12.28 \pm 0.61$ & $7.19 \pm 0.36$ & $1.49 \pm 0.07$ \\
\hline \multicolumn{4}{|c|}{ Overall percentage composition for: } & $\begin{array}{l}\mathrm{N} \text {-alkane } \\
\text { Branched alkane }\end{array}$ & $\begin{array}{l}47.48 \% \\
38.04 \%\end{array}$ & $\begin{array}{l}25.51 \% \\
55.32 \%\end{array}$ & $\begin{array}{l}14.40 \% \\
41.86 \%\end{array}$ \\
\hline
\end{tabular}

*The prevailing CHCs used for quantitation and correlation studies

The mean relative abundance for aliphatic alkanes $(n-\mathrm{C} 27$ and $n$-C29) reduced progressively over the three different intervals of exposure i.e. $47.48 \%$ (day-0), $25.51 \%$ (day-7) and $14.40 \%$ (day-14). In contrast, variations in the mean relative abundance of branched alkanes i.e. 38.04\% (day-0), 55.32\% (day-7) and 41.86\% (day-14) were observed. Although the mean \pm SD relative abundance for tetradecane ( $n$-C17, peak 1$)$ had increased progressively from day- $0(25.98 \pm 1.30 \%)$ to day-14 $(40.40 \pm 2.02 \%)$, the same pattern of progressive increase was not observed for the remaining peaks for branched alkanes (peaks 2, 3, 5, 13 and 16).

Considering the high similarity in the chromatographic profiles obtained from the three different weathering intervals, representative GC-MS chromatogram for the pupal cases of C. megacephala at day-0 alone is presented here (Figure 3(a)). Unlike the significant changes in the chromatographic profile of the CHC in the pupal cases during the 30,60 and 90 days weathering intervals reported by previous researchers [8], specific changes in the obtained chromatographic profiles during the three weathering intervals analyzed here were not found. The high similarity in the chromatographic profiles of CHCs observed in this present research may be attributable to the fact that the pupal cases were only subjected to relatively shorter durations of weathering interval (up to 14 days) than that of 90-day interval studied by Zhu et al.[8]. Weathering interval apart, the high similarity in the 


\section{Nurul Nadhirah et al: CUTICULAR HYDROCARBONS OF PUPAL CASES OF Chrysomya megacephala (FABRICIUS) AND ITS POSSIBLE USE FOR ESTIMATING POSTMORTEM INTERVAL}

chromatographic profiles may also be due to relatively small variations in the weathering conditions observed in this present research, an avenue for further study. Since Zhu et al. [8] did not provide the detailed daily ambient conditions by which the weathering process took place, suitable comparison with the findings reported here could not be made. Because $n$-C27 and $n$-C29 were consistently observed in all the samples, and their relative abundances progressively reduced over time, formulating credible mathematical algorithms for associating such concentrations with that of durations of weathering process may provide a useful means for estimating the age of the pupal cases recovered at the crime scene.

Concentrations of two prevailing hydrocarbons in the CHC compositions of $C$. megacephala pupal cases and its association with weathering intervals

In this present research, the prevailing CHCs (i.e. $n$-C27 and $n$-C29) in the pupal cases of $C$. megacephala buried in soil surrounding a decomposing beef meat substrate exposed to the three weathering intervals (day-0, day- 7 and day-14) were quantitated and the data are tabulated in Table 5. Such a finding was consistent with the indication made by Zhu et al. [8] that the relative mass abundance of aliphatic CHCs i.e. $n$-C27, $n$-C29, $n$-C31 and $n$-C33 'was expected to be a better indicator for the weathering time' in field experiments. Although Zhu et al. [7] reported a great abundance of odd numbered CHCs $(n-\mathrm{C} 29, n-\mathrm{C} 27, n-\mathrm{C} 31$ and $n-\mathrm{C} 25)$ in the pupal cases of $C$. megacephala within the laboratory setting, the abundance of even numbered $\mathrm{CHCs}$ was evidently increased with longer duration of weathering, observable from their tabulated data.

In a separate laboratory experiment, Ye et al. [19] reported that the $n$-C27 and $n$-C29 being the most abundant compounds found in the pupal cases of $C$. megacephala with $n$-C31 and $n$-C33 being undetected, similar to the observation reported in this present research. In this context, differences in climatic conditions [21-24], as well as soil microbiota at the decomposition site can be the determinant factors for variations observed in CHCs compositions. Therefore, in view of applying $\mathrm{CHC}$ analysis of $C$. megacephala pupal cases for estimating PMI in Malaysia, the relative mass abundance for the aliphatic CHCs of $n$-C27 and $n$-C29 may provide the better indicators for the weathering time exposure.

Table 5. Concentrations of heptacosane (n-C27) and nonacosane (n-C29) at three different weathering intervals

\begin{tabular}{lcccccc}
\hline & \multicolumn{3}{c}{ Descriptive Statistic } & \multicolumn{3}{c}{ Comparison Among Weeks of Exposure } \\
\cline { 2 - 7 } $\begin{array}{l}\text { Two prevailing } \\
\text { Hydrocarbons }\end{array}$ & $\begin{array}{c}\text { Day-0 } \\
(\boldsymbol{\mu g} / \mathbf{m L})\end{array}$ & $\begin{array}{c}\text { Day-7 } \\
(\boldsymbol{\mu g} / \mathbf{m L})\end{array}$ & $\begin{array}{c}\text { Day-14 } \\
(\boldsymbol{\mu g} / \mathbf{m L})\end{array}$ & $\begin{array}{c}\text { Day-0 versus } \\
\text { Day-7 }\end{array}$ & $\begin{array}{c}\text { Day-0 versus } \\
\text { Day-14 }\end{array}$ & $\begin{array}{c}\text { Day-7 versus } \\
\text { Day-14 }\end{array}$ \\
\hline $\begin{array}{l}\text { Heptacosane } \\
(n-C 27)\end{array}$ & $23.96 \pm 1.51$ & $9.07 \pm 0.11$ & $6.29 \pm 0.18$ & $\mathrm{P}<0.05$ & $\mathrm{P}<0.05$ & $\mathrm{P}<0.05$ \\
$\begin{array}{l}\text { Nonacosane } \\
(n-C 29)\end{array}$ & $43.76 \pm 0.83$ & $17.96 \pm 0.59$ & $7.72 \pm 0.23$ & $\mathrm{P}<0.05$ & $\mathrm{P}<0.05$ & $\mathrm{P}<0.05$ \\
\hline
\end{tabular}

Concentrations $(\mu \mathrm{g} / \mathrm{mL})$ of heptacosane $(n-\mathrm{C} 27)$ and nonacosane $(n-\mathrm{C} 29)$ are presented as mean \pm standard deviation. Oneway ANOVA with Tukey-Kramer post hoc test was used for comparing the concentrations of heptacosane $(n$-C27) and nonacosane ( $n$-C29) among the three durations of exposure.

In general, the concentration of $n$-C29 $(43.76-7.72 \mu \mathrm{g} / \mathrm{mL})$ was observably higher than that of $n$-C27 (23.96-6.29 $\mu \mathrm{g} / \mathrm{mL}$ ), with both the $n$-C27 and $n$-C29 concentrations showed decreasing pattern over the different weathering intervals. The highest concentrations of $n$-C27 and $n$-C29 were observed in pupal cases analysed on day-0, while the lowest being on day-14. Comparison using the One-way ANOVA with Tukey-Kramer post hoc test revealed significant decrease $(p<0.05)$ in the concentrations of both the $n$-C27 and $n$-C29 across the three different weathering intervals analysed in this present research.

The significant decrease $(p<0.05)$ in the concentrations of aliphatic CHCs $n$-C27 and $n$-C29 observed in this present research was consistent with observation made in a field work reported by Zhu et al. [8]. The decrease can be attributable to degradation by abiotic factors such as the prevailing climatic conditions [17, 29] (e.g. ambient temperature, relative humidity and rainfall), as well as soil physicochemical parameters (temperature, $\mathrm{pH}$, water 
content, oxygen and inorganic nutrients) [30]. Such conditions would cause evaporation, dissolution, dispersion, emulsification, adsorption on suspended materials, as well as photooxidation of the aliphatic CHCs (n-C27 and nC29), hence reducing their concentrations [31].

Abiotic factor apart, degradation of the hydrocarbons by the soil microbiota such as Pseudomonas aeruginosa has also been reported in the literature [30]. Besides, many other microorganisms have been reported to exhibit the ability to use complex pathways for degrading n-alkanes into carbon dioxide and water as their growth substrates [32]. In this context, Berthe-Corti and Fetzner [33] indicated that spontaneous oxidation of n-alkane as the pivotal player in its degradation into fatty acids.

The associations between the concentrations of aliphatic $\mathrm{CHC} n$-C27 and $n$-C29 in the pupal cases of $C$. megacephala with that of the weathering intervals are presented in Table 6. The Pearson correlation coefficients for $n$-C27 and $n$-C29 were -0.926 and -0.970 , respectively; the regression values being 0.857 and 0.941 , correspondingly. Considering the categorical definition of the strength of correlation coefficient prescribed by Munro [13], the concentrations observed for these two aliphatic CHCs can be construed as 'very high'. The 'very high' strength of correlation coefficient observed here statistically supports the usefulness of the association for decision making. Therefore, it is possible to suggest formulation of credible mathematical algorithm for relating the concentrations of $n-\mathrm{C} 27$ and $n-\mathrm{C} 29$ in the pupal cases of $C$. megacephala with that of the three weathering intervals evaluated here.

Table 6. Association between the concentrations of $n$-C27 and $n$-C29 in the pupal cases of C. megacephala with that of weathering intervals

\begin{tabular}{lcccc}
\hline $\begin{array}{l}\text { Two Prevailing } \\
\text { Hydrocarbons }\end{array}$ & \multicolumn{3}{c}{$\begin{array}{c}\text { Pearson Correlation Coefficients (r) and Regressions (r2) between the } \\
\text { Concentrations of } \mathbf{n}-\mathbf{C 2 7} \text { and } \mathbf{n}-\mathbf{C 2 9} \text { in the Pupal Cases of } \boldsymbol{C} \text {. megacephala } \text { and } \\
\text { Weathering Intervals }\end{array}$} \\
\cline { 2 - 5 } & $\mathrm{r}$ values & $\boldsymbol{p}$ values & $\mathbf{r}^{2}$ values & $\begin{array}{l}\text { Regression } \\
\text { Equation }\end{array}$ \\
\hline Heptacosane $(n-\mathrm{C} 27)$ & -0.926 & $\mathrm{P}<0.05$ & 0.857 & $\mathrm{y}=21.942-8.837 \mathrm{x}$ \\
Nonacosane $(n-\mathrm{C} 29)$ & -0.970 & $\mathrm{P}<0.05$ & 0.941 & $\mathrm{y}=41.167-18.020 \mathrm{x}$ \\
\hline
\end{tabular}

Munro [13] prescribed the strength of association as follows: 0.00- 0.025 (little if any); 0.26-0.49 (low); 0.50-0.69 (moderate); 0.70-0.89 (high); 0.90-1.00 (very high).

\section{Conclusion}

The results of this present research further accentuate the proposition made by Zhu et al. that the decomposition of $\mathrm{CHC}$ 'is theoretically predictable in fresh puparia and changes regularly over time' [8]. Thus, analyzing $\mathrm{CHC}$ compositions in the pupal cases of $C$. megacephala for estimating the weathering time that they were exposed to the environment, for providing suitable information for estimating late PMI in Malaysia perspective, appears forensically feasible. This finding throws light at appreciating the currently-neglected pupal cases that are commonly found at crime scenes as an important piece of physical evidence.

\section{Acknowledgement}

We are thankful to Universiti Teknologi Malaysia for providing Research University Grants (Q.J130000.2526.16H92 and Q.J130000.2626.09J64) for conducting this research project.

\section{References}

1. Gennard, D. (2012). Forensic entomology: An introduction. Wiley Press.

2. Mahat, N. A., Yin, C. L., and Jayaprakash, P. T. (2014). Influence of paraquat on Chrysomya megacephala (Fabricius) (Diptera: Calliphoridae) infesting minced-beef substrates in Kelantan, Malaysia. Journal of Forensic Sciences, 59(2): 529-532. 
Nurul Nadhirah et al: CUTICULAR HYDROCARBONS OF PUPAL CASES OF Chrysomya megacephala (FABRICIUS) AND ITS POSSIBLE USE FOR ESTIMATING POSTMORTEM INTERVAL

3. Kavitha, R., Nazni, W. A., Tan, T. C., Lee, H. L., and Azirun, M. S. (2013). Review of forensically important entomological specimens collected from human cadavers in Malaysia (2005-2010). Journal of Forensic and Legal Medicine, 20(5): 480-482.

4. Mahat, N. A. and Jayaprakash, P. T. (2013). Forensic entomology in Malaysia: A review. Malaysian Journal of Forensic Sciences, 4(1): 1-6.

5. Lee, H. L. (1989). Recovery of forensically important entomological specimens from human cadavers in Malaysia-an update. Malaysian Journal of Pathology, 11: 33-36.

6. Mahat, N. A., Zafarina, Z., and Jayaprakash, P. T. (2009). Influence of rain and malathion on the oviposition and development of blowflies (Diptera: Calliphoridae) infesting rabbit carcasses in Kelantan, Malaysia. Forensic Science International, 192(1-3): 19-28.

7. Zhu, G. H., Xu, X. H., Yu, X. J., Zhang, Y., and Wang, J. F. (2007). Puparial case hydrocarbons of Chrysomya megacephala as an indicator of the postmortem interval. Forensic Sci International, 169(1): 1-5.

8. Zhu, G.-H., Yu, X.-J., Xie, L.-X., Luo, H., Wang, D., Lv, J.-Y. and Xu, X.-H. (2013). Time of death revealed by hydrocarbons of empty puparia of Chrysomya megacephala (Fabricius) (Diptera: Calliphoridae): A field experiment. PLoS ONE, 8(9): e73043.

9. Zhu, G. H., Ye, G. Y., Hu, C., Xu, X. H. and Li, K. (2006). Development changes of cuticular hydrocarbons in Chrysomya rufifacies larvae: potential for determining larval age. Medical and Veterinary Entomology, 20(4): 438-44.

10. Malaysian Meteorological Department (2015). Retrieved from the Malaysia Meteorological Department website: http://www.met.gov.my [Date access 20 June 2015].

11. Omar, B., Marwi, M., Oothuman, P., and Othman, H. (1994). Observations on the behaviour of immatures and adults of some Malaysian sarcosaprophagous flies. Tropical Biomedicine, 11: 149-149.

12. Chau, J. F., Bagtzoglou, A. C., and Willig, M. R. (2011). The effect of soil texture on richness and diversity of bacterial communities. Environmental Forensics, 12(4): 333-341.

13. Munro, B. H. (2005). Statistical methods for health care research. Lippincott Williams \& Wilkins.

14. Miuc, A., Voncina, E. and Lecnik, U. (2015). Composition of organic compounds adsorbed on $\mathrm{PM}_{10}$ in the air above maribor. Acta Chimica Slovenia, 62(4): 834-848.

15. USFDA (2001). Guidance for industry: Bioanalytical method validation. U.S. Department of Health and Human Services Food and Drug Administration- Center for Drug Evaluation and Research (CDER)-Center for Veterinary Medicine (CVM).

16. Tiwari, G. and Tiwari, R. (2010). Bioanalytical method validation: An updated review. Pharmaceutical Methods, 1(1): 25-38.

17. Serrano, A., Gallego, M., González, J. L., and Tejada, M. (2008). Natural attenuation of diesel aliphatic hydrocarbons in contaminated agricultural soil. Environmental Pollution, 151(3): 494-502.

18. Sharma, R., Kumar Garg, R., and Gaur, J. R. (2015). Various methods for the estimation of the post mortem interval from Calliphoridae: A review. Egyptian Journal of Forensic Sciences, 5(1): 1-12.

19. Ye, G., Li, K., Zhu, J., Zhu, G., and Hu, C. (2007). Cuticular hydrocarbon composition in pupal exuviae for taxonomic differentiation of six necrophagous flies. J Med Entomol. 44(3): p. 450-456.

20. Frere, B., Suchaud, F., Bernier, G., Cottin, F., Vincent, B., Dourel, L., Lelong, A. and Arpino, P. (2014). GCMS analysis of cuticular lipids in recent and older scavenger insect puparia. An approach to estimate the postmortem interval (PMI). Anal Bioanalytical Chemistry, 406(4): 1081-1088.

21. Wagner, D., Tissot, M. and Gordon, D. (2001). Task-related environment alters the cuticular hydrocarbon composition of harvester ants. Journal Chemical Ecology, 27(9): 1805-1819.

22. Savarit, F. and Ferveur, J. F. (2002). Temperature affects the ontogeny of sexually dimorphic cuticular hydrocarbons in Drosophila melanogaster. Journal Expimental Biology, 205(20): 3241-3249.

23. Ingleby, F. C. (2015). Insect cuticular hydrocarbons as dynamic traits in sexual communication. Insects, 6(3): 732-742.

24. Ingleby, F. C., Hosken, D. J., Flowers, K., Hawkes, M. F., Lane, S. M., Rapkin, J., House, C. M., Sharma, M. D. and and Hunt, J. (2014). Environmental heterogeneity, multivariate sexual selection and genetic constraints on cuticular hydrocarbons in Drosophila simulans. Journal of Evolution Biology, 27(4): 700-713.

25. Trewin (2014). The climates of the tropics and how they are changing. In Harding, S., McComiskie, R., Wolff, M., Trewin, D., and Hunter, S. (Eds.). State of the Tropics 2014 Report (pp. 39-51). Australia, James Cook University. 
26. Pechal, J. L., Moore, H., Drijfhout, F. and Benbow, M. E. (2014). Hydrocarbon profiles throughout adult Calliphoridae aging: A promising tool for forensic entomology. Forensic Sci International, 245: 65-71.

27. Sarkar, N., Mukherjee, A. and Barik, A. (2013). Long-chain alkanes: Allelochemicals for host location by the insect pest, Epilachna dodecastigma (Coleoptera: Coccinellidae). Applied Entomology and Zoology, 48(2): 171-179.

28. Bettelheim, F. A., Brown, W. H., Campbell, M. K. and Farrell, S. O. (2009). Introduction to general, organic and biochemistry. Cengage Learning Publication.

29. Hejazi, R. F. and Husain, T. (2004). Landfarm performance under arid conditions. 2. Evaluation of parameters. Environmental Science Technology, 38(8): 2457-2469.

30. Sharma, A., Kumar, P. and Rehman, M. B. (2014). Biodegradation of diesel hydrocarbon in soil by bioaugmentation of Pseudomonas aeruginosa: A laboratory scale study. International Journal of Environmental Bioremediation \& Biodegradation, 2(4): 202-212.

31. Wang, Z., Fingas, M., Lambert, P., Zeng, G., Yang, C. and Hollebone, B. (2004). Characterization and identification of the Detroit River mystery oil spill. Journal of Chromatography A, 1038(1-2): 201-214.

32. Dibble, J. T. and Bartha, R. (1979). Effect of environmental parameters on the biodegradation of oil sludge. Applied and Environmental Microbiology, 37(4): 729-739.

33. Berthe-Corti, L. and Fetzner, S. (2002). Bacterial metabolism of n-alkanes and ammonia under oxic, suboxic and anoxic conditions. Acta Biotechnologica, 22(3-4): 299-336. 